https://journal.uwgm.ac.id/index.php/abdimasmahakam

E-ISSN: 2549-5755

Januari 2020, Vol. 4 No. 01

Received: Oktober 2019

Accepted: Desember 2019

Published: Januari 2020

Article DOI: http://dx.doi.org/ 10.24903/jam.v4i1.783

\title{
Seminar tentang Peranan Budaya terhadap Perkembangan Nilai-nilai Agama dan Moral Anak Usia Dini
}

\author{
Hanita \\ Universitas Widya Gama Mahakam Samarinda \\ nitahanita87@gmail.com \\ Ayu Memeliana \\ ayumemelina792@gmail.com \\ Universitas Widya Gama Mahakam Samarinda \\ Nuryanti \\ nuryanti.21@yahoo.com \\ Universitas Widya Gama Mahakam Samarinda
}

\begin{abstract}
Abstrak
Pengenalan budaya pada anak tidak terlepas dari pengaruh pendidikan dilingkungan rumah maupun di sekolah. Budaya merupakan bagian dari kebiasaan sehari-hari yang tumbuh dan berkembang di masyarakat, Sehingga kebutuhan pendidikan semakin meningkat. Pemahaman pendidikan secara keseluruhan upaya meningkatkan kemampuan dan potensi nilai-nilai sosial budaya dan rasa kemanusiaan secara utuh pada anak usia dini. Dalam pembelajaran aspek perkembangan agama dan moral berkaitan tentang perkembagan sikap dan tingkah laku anak. Melaksanakan ajaran sesuai agama yang dianut dalam kehidupan sehari-hari. Pada kegiatan ini memiliki tujuan untuk menyampaikan bagaimana membetuk perilaku terpuji dan tidak terpuji, serta taat dalam menjalankan aturan yang ada perintah agamanya dan sesuai dengan pembiasaan budaya, yang mendasari prilaku dan sikapnya terhadap kehidupan selanjutnya baik masa kanak-kanak, remaja, dewasa dan orang tua. Metode yang digunakan dalam kegiatan ini adalah dengan penyuluhan dan evaluasi melalui angket. Hasil berdasarkan pertanyaan kepada para guru dan orang tua, menunjukkan bahwa adanya peranan budaya terhadap peningkatan nilai-nilai agama dan moral yang dibuktikan dari hasil persentase point 3 (sering) sebanyak 96,36\% pada Penilaian Penananaman Nilai-Nilai Agama Dan Moral, point 3 (sering) sebanyak $75 \%$ pada penilaian terhadap budya (pembiasaan) pada anak usia dini. Penerapan serta menanamkan perilaku nilai agama serta moral, disiplin dan afeksi dalam upaya pembentukan bidang perilaku yang merupakan kegiatan secara terus menerus dilakukan dan dibiasakan pada kegiatan sehari-hari anak, sehingga aspek ini secara optimal mengalami perkembangan.
\end{abstract}

Kata Kunci: budaya; nilai-nilai Agama; dan moral 


\section{(A) ABDIMAS \\ https://journal.uwgm.ac.id/index.php/abdimasmahakam}

E-ISSN: 2549-5755

Januari 2020, Vol. 4 No. 01

\section{Pendahuluan}

Kejadian yang terjadi pada beberapa dekade ini pada umumnya kebanyakan anak-anak Indonesia mengalami turunnya nilai-nilai moral dan agama yang diakibatkan oleh pengaruh budaya - budaya yang bersumber dari luar. Budaya lokal mulai dilupakan bahkan sampai di tinggalkan. Sebagian mengangap budaya lokal merupakan budaya kuno dan tidak dianggap moderen. Sehingga generasi sekarang banyak meninggalkannya. Pengenalan budaya lokal tidak terlepas dari pengaruh pendidikan baik di sekolah maupun di rumah. Budaya merupakan bagian dari kebiasaan sehari-hari yang tumbuh dan berkembang di masyarakat, Sehingga kebutuhan pendidikan semakin meningkat. Pemahaman pelaksanaan Pendidikan secara keseluruhan adalah untuk mengembangan kemampuan secara utuh rasa kemanusiaan serta penanaman nilai-nilai sosial budaya. Dalam meningkatkan perkembangan nilai agama dan moral berkaitan dengan bagaimana penanaman budi pekerti, sikap dan perilaku yang santun serta adanya kemauan untuk menjalankan serta melaksanakan ajaran agama yang dianut dalam kehidupan sehari-hari (Anggraini and Syafril 2018).

Dalam pembelajaran aspek perkembangan Agama dan nilai-nilai berkaitan tentang perkembagan sikap dan tingkah laku anak. Melaksanakan Agama yang dianut dan menjalankan ajaran agamanya sesuai dengan yang dianutnya, disetiap kehidupan sehari-hari. Stimulus tentang perkembangan aspek nilai agama serta moral memiliki tujuan untuk membetuk perilaku baik dan buruk taat dalam menjalankan perintah agamanya dan sesuai dengan budaya. Menanamkan kemampuan aspek agama dan nilai-nilai moral terutama pada anak usia dini dimaksudkan sebagai pembentukan serta perubahan psikis dan rohani yang berhubungan dengan kemampuan untuk memahami serta bertindak sesuai dengan ajaran agama yang dianut serta budayanya. Dalam hal yang dibahas dalam kasus metro.sindonews.com, mengatakan bahwa bahwa ketua Komnas PA, Bapak Arist Merdeka Sirait mengatakan bawa " kasusu kekerasan pada anak makin meninggkat setiap tahunnya. Dideteksi mulai tahun 2010 hingga 2015 saja kurang lebih 10 juta anak menjadi korban kekerasan terutama dari 58\% adalah kekerasan seksual ". Ditambah dengan masalah narkoba, bullying, mencuri dan lain sebaginya. Hal ini menjadi satu hal yang menyebabkan semakin banyak maslah sehingga menggelisahkan bangsa Indonesia. Dari pembahasan ini mama ini menjunkkan bawa pengelolaan lembaga pendidikan belum maksimal menanamkan nilai agama serta moral pada anak didik, yang itu merupakan pondasi dalam membentul perilaku (Tanfidiyah 2017).

Adanya penyimpangan nilai agama dan moral pada lingkungan yang lebih kecil mulai terlihat dari proses pembelajaran serta mulai ditinggalkanya budaya yang menjadi penciri bangsa indonesia terutama dilingkungan Lempake. Memberikan penanaman pada anak usia dini pada aspek nilai-nilai agama dan moral merupakan mendasari prilaku dan sikapnya terhadap kehidupan selanjutnya baik masa kanak-kanak, remaja, dewasa dan orang tua.

\section{Metode}

Pada kegiatan ini menjadi peserta adalah para Guru PAUD dan orang tua terutama dilingkungan sekolah KB Tunas Harapan Lempake Samarinda. Pelaksanaan Pengabdian ini tentu saja melibatkan beberapa pihak yaitu beberapa anggota Hima PG PAUD UWGM Samarinda, yang bertindak sebagai panitia pelaksana kegiatan. Pengabdian kepada Masyarakat ini menggunakan metode ceramah dengan teknik presentasi materi karya 


\section{(A) ABDIMAS}

https://journal.uwgm.ac.id/index.php/abdimasmahakam

E-ISSN: 2549-5755

Januari 2020, Vol. 4 No. 01

pengembangan profesi dilanjutkan dengan diskusi serta penyebaran angket. Pelaksanaan pengabdian masyarakat ini diberiakan kepada para pendidik di ruang kelas di KB Tunas Harapan Lempake Samarinda. Berkenaan waktu rencana pelaksanaanya pada bulan 23 November 2019.

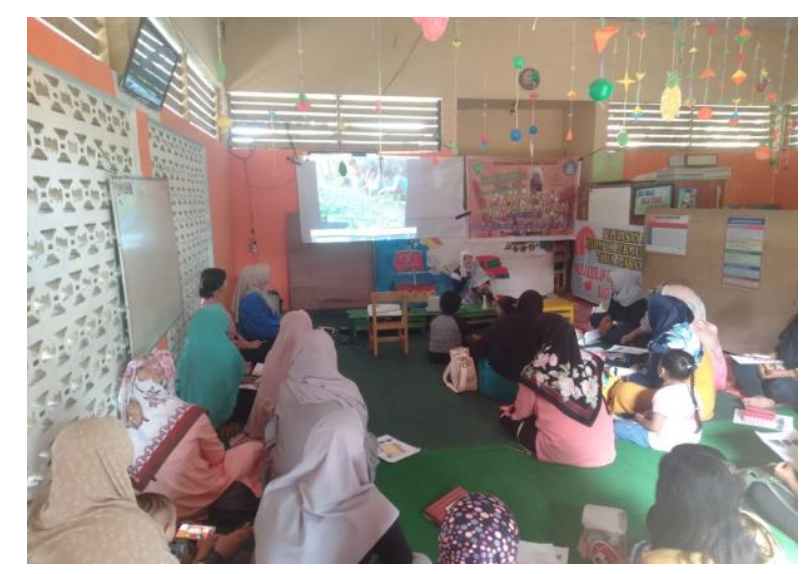

Gambar.1. kegiatan seminar

\section{Hasil dan Pembahasan}

Dalam kehidupan masyarakat terutama dalam berinteraksi dengan lingkungan sosialnya yang merupakan hal yang menjadi Pondasi yang kokoh serta peraan yang sangat penting yaitu Pendidikan serta pengetahuan dari segi aspek kemampuan nilai-nilai agama dan moral. Penananaman dan stimulus dari aspek ini membuat anak dari sejak dini mendapatkan pendidikan yang baik dalam upaya untuk suap menjalani jenjang dan tahap pendidikan selanjutnya. Praktek prilaku etika, beribadah, serta spoan santun yang berbudi luhur saat diberikan sebagai pelajaran tidak akan cukup tapi juga di jadikan sebagai pembiasaan prilaku yang diasah serta dikembangkan melalui beberapa tahap yaitu; 1) pengetahuan (knowing), 2) tahap pelaksanaan (acting), serta 3) tahap kebiasaan (habit). Menjadi sebuah kebiasaan seseorang dalam bertindak yang didasari oleh pengetahuannya belum mampu sesuai dengan apa yang ada dilingkungan yang dihadapai. Perlu latihan untuk mampu mengasah sesuatu menjadi kebiasaan tersebut.

Adapun Fungsi kebudayaan terhadap manayarakat adalah; 1)Untuk melindungi diri serta beradaptasi lingkungan terhadap alam sekitar tempat tinggal masyarakat, 2) Untuk mengatur hubungan antar manusia. Budaya terbentuk dalam upaya untuk mengatur hubungan anatar manusia agar mampu memahami seperti apa cara bertindak dan membentuk sikap bagaimana cara bersosialisasi dengan lingkungan serta masyarakat. Menciptakan kebiasaan didalam masyarakat dan membentuk sebuah perilaku pribadi individual, dan kemampuan pribadi yang ini membentuk sebuah aturan. Budaya juga sebagai wadah dari segenap perasaan manusia, Masyarakat ialah kumpulan individu yang hidup bersama dalam jangka waktu tertentu dan menciptakan kebudayaan; 1) setiap masayarakat pasti memiliki kebudayaan, 2) adanya kebudayaan pasti ada masyarakat . Setiap masyarakat memiliki budaya berbeda yang disebabkan oleh latar belakangnya, Misalnya: Suku Jawa vs Suku Banjar, Berbeda perilaku karena pengaruh geografis, ekonomi.

Adapun macam-macam budaya dari skala bangsa dan negara, kebudayaan dibagi dua: 1) 


\section{(A) ABDIMAS}

https://journal.uwgm.ac.id/index.php/abdimasmahakam

E-ISSN: 2549-5755

Januari 2020, Vol. 4 No. 01

Kebudayaan umum (Nasional). contoh: Bendera merah putih merupakan budya masyarakat Indonesia secara keseluruhan, maka budaya nasional telah diakui serta dimiliki oleh semua masyarakat Indonesia, 2) Kebudayaan sub culture (lokal); baju adat disetiap daerah di negara Indonesia memiliki perbedaan dan disesuaikan dengan keadaan dan ciri has daerah masingmasing, maka budaya sub culture (lokal).

Budaya dipengaruhi oleh pembiasaan selalu muncul akibat adanya kepribadian individu yang ada disekitarnya, antara lain ;1) budaya secara khusus didasari kedaerahan, 2) kebiasaan cara hidup didesa dan dikota (rural and urban society, 3) budya didasari oleh keadaan sosial, 4) budya didasari oleh keyakinan agama yang dianut, 5) budya didasari oleh kemampuan dasar dan keahlian seseorang. Pada kategori budaya antara hubungan antar suku bangsa. Proses integrasi antar suku bangsa di Indonesia terjadi melalui perkawinan antar suku bangsa, baik nasional ataupun internasional. Pesatnya komunikasi dan teknologi, memberikan nilai keterbukaan dan meminimalisir perilaku sukuisme. Terbentuknya sebuah suku, ras serta golongan ini didasari oleh latar belakang yang berbeda dari segi sosial serta budaya setempat. Hal tersebut membentuk cara berfikir, sikap, dan tindakan yang berbeda pula.

John Dewey berpendapat bahwa tahapan perkembangan moral melewati tiga fase antara lain : 1) fase premoral (preconventional): pada level ini sikap dan perilaku manusia banyak dilandasi oleh impuls biologis dan sosial, 2) tingkat konvensional : perkembangan moral banyak didasari oleh sikap manusia kritis kelompoknya, 3) autonomous : perkembangan moral banyak dilandasi pola pikirnya sendiri. Dalam fase ini anak memiliki kemampuan tersendiri yang termebntuk melalui stimulus yang anak dapat serta keputusan anak dalam bersikap (Inawati 2017). Lingkungan sosial anak sangat menentukan pola tahapan perkembangan seorang anak. Tata cara pola pengasuhan para oramg tua terhadap anak akan mempengaruhi hal yang diterima oleh anak dari nilai-nilai positif atau negatif yang anak terima. Maka itu akan melakat dan menjadi probadi dalam diri seoranga anak. Perkembangan anak menjadi salah elemen yang paling penting dan beroengaruh terhadap perkembangan sosial masyarakat yang baik dan kondusif. Perkembangan bagi otak anak terjadi pada usia nol sampai lima tahun yang disebut dengan masa keemasan, dimana otak anak berkembang dengan pesat serta mudah menrima stumulus dari luar. Dimasa ini alur belajar anak tentang karekter, sikap, intelektual, emosi dan moral manusia dibentuk. Semakin bagus kualitas stimulus pada anak maka berarti semakin banyak dan bagus jalur belajar yang dibentuk otaknya.

Pendidikan prilaku anak terutama dalam kemampuan nilai - nilai agama dan moral dalam upaya untuk menyentuh dimensi dasar kemanusiaan maka harus mendapatkan. Dimensi kemanusiaan itu mencakup sekurang-kurangnya tiga hal paling aspek mendasar yaitu afektif, kognitif serta psikomotor. Nilai-nilai sikap dan prilaku yang perlu ditimulus serta diterapkan secara berkelanjutan pada anak menurut yang perlu diajarkan menurut Dr Sukamto; 1) kejujuran , 2) loyalitas dan dapat diandalkan, 3) hormat , 4) cinta, 5) ketidak egoisan dan sensitifitas, 6) baik hati dan pertemanan, 7) keberanian, 8) kedamaian , 9) mandiri dan potensial, 10) disiplin diri dan moderasi, 11) kesetiaan dan kemurnian, 12) keadilan dan kasih sayang.

Adapun cara menanamkan kemampuan aspek ini dengan strategi antara lain : a) menanamkan rasa cinta kepada allah swt, b) menciptakan rasa aman, c) mencium dan membelai anak, d) menanamkan cinta tanah air, c) meneliti dan mengamati, d) menyentuh dan mengaktikan potensi berfikir anak, e) memberikan penghargaan, f) pendidikan jasmani, g) teladan yang 


\section{(A) ABDIMAS}

https://journal.uwgm.ac.id/index.php/abdimasmahakam

E-ISSN: 2549-5755

Januari 2020, Vol. 4 No. 01

baik, h) pengulangan dalam proses pembelajaran, i) memenuhi kebutuhan bermain.

Adapun penilaian menggunakan angket dalam upaya mengukur atau menilai hasil peranan budaya terhadap perkembangan nilai-nilai agama dan moral anak. Penilaian penananaman nilai-nilai agama dan moral terdiri dari : 1) mengajarkan anak bersikap baik terhadap orang lain, 2) mengajarkan anak untuk berempati kepada orang lain, 3) mengajarkan anak mengenal tata cara bersikap positif, 4) menanamkan sikap moral dan akhlak terpuji pada anak, 5) menanamkan kepada anak cara berbicara yang baik dan sopan terhadap orang lain , 6) mengajarkan berdoa sebelum dan sesudah makan, 7) mengajarkan anak mengenali cara mengetahui perbuatan baik dan buruk, 8) engajarkan anak suka menolong, 9) mengajarkan anak untuk mau berbagi dengan temannya, 10) menanamkan kepada anak perilaku menjaga kebersihan lingkungan (Arsita 2017).

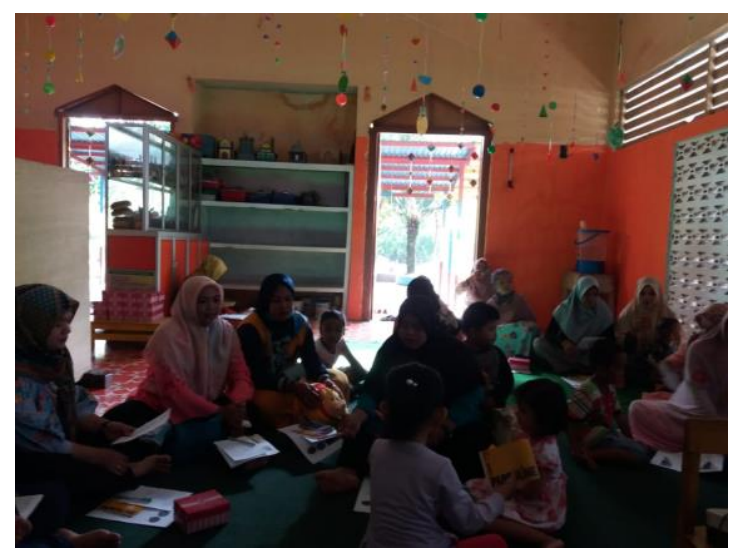

Gambar.2. Kegiatan Pengisian Angket

Hasil dari angket yang dibagian memiliki tiga tingkatan penilaian, yaitu, point 1 (tidak pernah), point 2 (kadang-kadang), dan point 3 (sering). Hasil yang didapat point 1 (tidak pernah) sebayak $0 \%$, point 2 (kadang-kadang) sebayak 2,27\% dan point 3 (sering) sebanyak 96,36\%. Dar hasil menunjukkan bahwa setiap orang tua dan guru telah memberikan pembiasaan atau dengan kata lain memberikan budaya yang mengasah kemampuan ini.

Penilaian terhadap budaya (pembiasaan) pada anak usia dini, antara lain ; 1) anak terbiasa berucap salam sebelum dan sesudah keluar rumah, 2) anak terniasa berbagi dengan temannya, 3) anak terbisa berkata sopan, 4) anak terbiasa menunjukkan sikap positif, 5) anak terbiasa bersalaman (cium tangan) sebelum dan sesudah keluar baik di sekolah maupun di rumah, 6) anak terbiasa menolong temannya, 7) anak terbiasa merawat dan menjaga mainan agar tidak rusak, 8) anak terbiasa membuang sampah pada tempatnya, 9) anak terbiasa berdoa sebelum dan sesudah makan, 10) nak terbiasa mengatakan terimakasih saat diberikan sesuatu (Linda Arsita 2017).

Hasil dari angket yang dibagian memiliki tiga tingkatan penilaian sama dengan penilaian nilai-nilai agama dan moral yaitu, point 1 (tidak pernah), point 2 (kadang-kadang), dan point 3 (sering). Hasil yang didapat point 1 (tidak pernah) sebayak $0,45 \%$, point 2 (kadangkadang) sebayak $24,55 \%$ dan point 3 (sering) sebanyak $75 \%$. Hasil tersebut menunjukkan bahwa anak menunjukkan sikap yang mencerminkan perilaku yang sesuai dengan nilai-nilai agama dan moral. 
Isi dari pernyataan PUSKUR (Pusat Kurikulum) 2002, secara umum pendidikan pada anak usia dini memiliki tujuan untuk berperan dalam membantu mengembangkan dan meningkatkan seluruh potensi serta kemampuan fisik, intelektual, emosional, agama dan moral secara optimal pada anak dalam lingkungan pendidikan yang kondusif, demokratis, dan kompotitif (Nurwita 2019). Cara mengembangkan kemampuan nilai-nilai agama dan nilai moral yang dapat menggunakan teknik yang bisa dilakukan oleh guru atau pendidik dengan cara melakukan berkomunikasi dan interaksi, Cara-cara tersebut antara lain (Kanakkanak n.d.); a) Membiarkan , maksud membiarkan adalam menerima perbuatan dan prilaku anak selama anak tidak melakukan perbuatan yang tidak terpuji serta merusak, b) guru menberikan contoh kepada anak dalam bentuk perilaku yang baik yang mudah ditiru anak, cara ini menjadi hal yang paling mudah dan efektif dalam membtuk perilaku moral anak, c) mengalihkan arah (redirecting), maksud dari cara ini adalah bagaimana seorang guru atau orang tua mampu memberikan pengalihan saat anak melakukan tindakan atau perbuatan yang menyimpang atau tidak terpuji. Teknik ini mampu memberikan alternatif dalam hal pembimbingan dan pembelajaran moral kepada anak, d) Memberikan pujian terhadap anak menunjukkan dukungan dan motivasi guru dan orang tua dari semua hal yang positif yang anak alakukan, e) Melakukan kegiatan mengajak anak dalam melakukan sesuatu dalam upaya membangun perasaan serta emosi untuk mendorong keiinginan serta ide anak, f) Mengajak anak untuk melakukan kegiatan yang menantang (challengging) untuk mengasah serta menguji kemampuan, ketelitian serta tanggung jawab anak.

Strategi dalam meiningkatkan dan mengmbangkan nilai-nilai agama dan moral dengan membimbing anak melalui cara menanamkan rasa cinta kepada Allah SWT, memberikan rasa aman yang menrupakan kebutuhan mendasar, memberikan rasa kasih sayang kepada anak dengan mencium dan membelai anak, menumbuhkan dan menanamkan rasa cinta tanah air kepada anak, memberikan kesempatan dan memfasilitasi anak untu mengasah rasa ingin tahu dengan menelti dan mengamati, menberikan kegiatan yang mengatifkan potensi berfikir anak, memberikan penghargaan pada dalam upaya memberika motivasi kepada anak untu lebih semangat mengasah kemampuannya, memberikan pendidikan jasmani untuk mengasah kemampuan anak dari aspek kemampuan motorik yang dapat mendukung berjalannya anak mengasah dan meningkatkan kemampuan nilai-nilai agama dan moral, orang tua dan guru menjadi teladan anak untuk mengasah kepribadiannya, memberikan kesempatan pengulangan dalam proses pembelajaran untuk memudahkan anak untuk memahami apa yang anak pelajari, memenuhi kebutuhan bermain anak karena bermain merupakan kebutuhan yang wajib dipenuhi (Inawati 2017).

Dari pembahasan di atas maka dapat dipahami bahwa memberikan sebuah pembiasaan dan budaya kepada anak sejak dini terutama dalam aspek kemapuan nilai-nilai moral dan agama akan membentuk anak menjadi seseorang yang memiliki pribadi yang baik, sehingga dapat menjadi hal yang penting dalam mentukan keadaan sosial dimasa yang akan datang. Dengan cara sering memberikan stimulis dan mebiasakan dalam memberikan latihan yang mengasah kemampuannya yang bersifat menanantang untuk mampu memberikan penilaian, membandingkan sera meneuntukan suatu tindakan yang akan dilakukan yang di dasari oleh hal mana yang boleh dan tidak boleh dilakukan menurut agama yang dianut serta budaya yang dimiliki. 


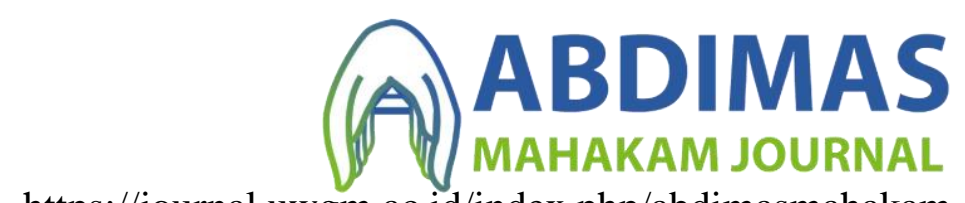

https://journal.uwgm.ac.id/index.php/abdimasmahakam

E-ISSN: 2549-5755

Januari 2020, Vol. 4 No. 01

\section{Simpulan dan rekomendasi}

Manusia merupakan ciptaan Tuhan yang terbaik dimuka bumi yang dilahirkan dalam keadaan suci. Kadaan bawan sejak lahir yang membawa potensi berdasarkan keturunan dan budaya. Para ilmuan menyatakan bahwa usia lahir sampai 6 tahun sesuai dengan PERMENDIKBUT RI No.137 th 2014 membahsa standar nasional PAUD.

Hasil berdasarkan pertanyaan dijawab oleh guru serta orang tua, menunjukkan bahwa adanya peranan budaya terhadap peningkatan nilai-nilai agama dan moral yang dibuktikan dari hasil persentase point 3 (sering) sebanyak 96,36\% pada Penilaian Penananaman Nilai-Nilai Agama Dan Moral, point 3 (sering) sebanyak $75 \%$ pada penilaian terhadap budya (pembiasaan) pada anak.

Kemampuan perkembangan nilai agama serta moral dapat dikenalkan dalam kegiatan seharihari dan terstruktur dalam rencana kegiatan pembelajaran harian terprogram, terintegrasi dan khusus. Kegiatan yang dilaksanakan secara rutin dapat dilakukan secara bersamaan dengan aspek perkembangan yang lain. Pembentukan aspek ini pada anak adalah pembinaan dilaksanakan secara terpadu, sehingga pada akhirnya semua konsep perilaku nilai agama serta moral anak dapat ditanamkan sangat baik dan melekat pada diri anak. 
https://journal.uwgm.ac.id/index.php/abdimasmahakam

E-ISSN: 2549-5755

Januari 2020, Vol. 4 No. 01

\section{Daftar Pustaka}

Accounting Principles Board (1970) APB 16 : Business Combinations, Business.

AICPA (2019) 'Consideration of Fraud in a Financial Statement', in Audit and Accounting Guide - Construction Contractors, 2019. doi: 10.1002/9781119679295.ch12.

Baridwan, Zaki (2004) Intermediate Accounting "Pengantar Akuntansi", Buku 2, Edisi 21, Salemba Empat. Jakarta.

Bodnar, George H and William S. Hopwood (2010) Accounting Information System. 10th edition. United State Of America: Pearson Education Inc.

Gitman, L.J.; Zutter, C.J (2012) Principles of Managerial Finance. 13e. Boston: Pearson.

Hutauruk, Martinus Robert (2017) Akuntansi Perusahaan Jasa. Aplikasi Program Zahir Accounting Versi 6. Indeks. Jakarta.

James A. O'Brien and Marakas, G. M. (2017) MANAGEMENT INFORMATION SYSTEMS Tenth Edition, McGraw-Hill Irwin.

Rama, D.V., dan L.J. Jones (2006) Sistem Informasi Akuntansi, Buku 1, Terjemahan oleh M. Slamet Wibowo, 2008, Jakarta: Salemba Empat.

SBR, T. K. P. R. B. (2017) 'SAK (Standar Akuntansi Keuangan Entitas Mikro, Kecil, Dan Menengah)', Sak Emkm.

Warren, C. S., Reeve, J. M. and Duchac, J. (2012) Financial and Managerial Accounting, Management Accounting Research. 